\title{
The Effectiveness of STEM Integrated Handouts to Improve Students Creative Thinking Skills in Biotechnology Material
}

\author{
Welly Mentari ${ }^{1 *}$, Abdurrahman ${ }^{1}$, T Jalmo $^{1}$ \\ ${ }^{1}$ Universitas Lampung, INDONESIA
}

Received 4 August 2019 - Revised 27 September 2019 - Accepted 26 October 2019

\begin{abstract}
This study aims to know the effectiveness of STEM integrated handouts to improve students creative thinking skills in biotechnology material. The design used was nonequivalent pre-post control group design. This research was implemented in grade IX of SMPN 25 Bandar Lampung, Indonesia. The subject were 70 students divided into experiment class $(\mathrm{N}=35)$ and control class $(\mathrm{N}=35)$ with purposive sampling technique. The data collection was done by pretest and posttest for students creative thinking skills and students responses to the STEM integrated handouts. Based on the result, it were obtained that an average $\mathrm{N}$-gain of experiment class was 0,64 greater than average $\mathrm{N}$-gain of control class was 0,40 . Both of class in medium category. Average $\mathrm{N}$-gain of fluency was 0,50 and originality was 0,66 with medium category, then average $\mathrm{N}$-gain of flexibility was 0,74 and elaboration was 0,79 with high category. The student responses showed almost all of the students agreed to the implementation of STEM integrated handouts improved interesting and motivating in biotechnology material.
\end{abstract}

Keywords: STEM, creative thinking skills, biotechnology

\section{INTRODUCTION}

The 21st century required students to have various skills and to be able to compete globally. One of thinking skills is creative thinking. Creative people will give satisfaction to the surrounding environment because the persons actions are carried out in a fast time, giving the right and many results, and the resulting work is original and unique [1]. Creative thinking is also needed to solve problems in the community. But in reality, Indonesian students thinking skills were still low, especially in science. It could be seen from the research of GCI (Global Creativity Index) 2015 which shows that Indonesia is ranked 115th of 139 countries [2]. Besides GCI, the results of the PISA study found shows that students thinking skills were still low. Students do not yet have the skills to become creative thinkers and problem solvers. This is supported by research [3] that the implementation of students creative thinking and conceptual understanding has not been implemented maximally yet because the teachers limited time to develop science learning tools to improve creative thinking skills and understanding concepts in science learning. In addition, most teachers still apply conventional learning, where the learning process only trains convergent thinking generally, so that when faced with a problem, students have difficulty solving problems creatively [4]. Based on the fact that creative thinking skills are not fully implemented, one of the learning approach to improve students creative thinking skills is STEM (Science, Technology, Engineering, and Mathematics) learning approach.

STEM is an important issue in education today [5] and is an alternative learning science that could build generations to face the challenging of 21st century [6] because STEM learning is an integration of learning science, technology, engineering, and mathematics that is suggested to help 21st century skill success [7]. The STEM approach aims to make better their understand when they do interaction in the community, they will be able to develop their competencies to various situations and problems in daily life [8]. STEM can develop when it is associated with the environment, so that a learning is realized that presents the real world experienced by students in daily life [9]. Therefore, the STEM approach is

(C) 2019 by the authors; licensee PGSD UMP. This article is an open access article distributed under the terms and conditions of the Creative Commons Attribution License (http://creativecommons.org/licenses/by/4.0/).

wellymentari@yahoo.com (*Correspondence) 
suitable for use in science learning because it could improve students to apply their knowledge to create designs as a form of solving problems related to the environment by utilizing technology. It was proved by research [10] that learning by integrating STEM knowledge is able to influence the level of creativity of students.

Based on the statement, it was needed STEM based learning through teaching materials and according to the students thinking skills. One teaching material that could be applied using the STEM-based learning approach is handouts. Handouts make learning "portable and enduring" (easy to carry everywhere and eternally) and recall information that has been obtained by students and develop tests for students [11] Besides that, handouts could increase students interested in learning, where students used handouts have a higher average value than students who do not use handout [12]. In addition, to increasing interest in learning, handouts could also improve students creative thinking skills. This is also supported by research [13] which states that handouts could improve students creative thinking skills that could be seen from the learning process of students before and after the use of handouts.

\section{MATERIAL AND METHODS}

\section{Methods}

This research method is quantitative with nonequivalent pre-post control group design. This research was conducted at SMPN 25 Bandar Lampung, Indonesia on February 2019, with population of 70 class IX students consisting of 35 experimental class students and 35 control class students by purposive sampling technique.

\section{Instrument}

The conception test instrument that was developed to find out the conception of preservice elementary school teacher students was 7 items. Test items used the four-tier test format. The conception test validation was judged by two physics education experts and one theoretical physicist. The results of the validation of the conception test items indicated that the validator generally stated that the items to be used are valid both in content and construction. Validators provided some notes that are suggested to be revised, especially those that are considered inappropriate, that is, related to accepted scientific theory, image clarity, sentence editorial, and written order. The research instrument was in the form of several multiple-choice items on the concept of force and motion that require explanations about the selected answers. To find out the participants' conceptual change, they wrote their responses towards several written statements (Yes/No/Not always) and with confidence levels (Sure/Not really sure/Not sure). The participants answered the questions individually and do not include their names to ensure their anonymity.

\section{Procedures}

In the preliminary study, Direct Instruction and discussion methods were used. After knowing the conceptual change profile that occurred, then the remedial teaching was conducted. It was adopted by the reflective conceptual change model of Chinn and Brewer (1993) and Aydenis and Brown (2010, 2017) and the cognitive conflict process model of Lee et al. (2003) and Hadjiachilleos et al. (2013), namely The Multimedia Visual Reflective Conceptual Change Model (RCCM). This learning model covering three stages, namely pre-learning, learning process and post- learning. The pre-learning goal is to uncover the initial predictions/ conceptions of the preservice elementary school teachers related to the concept of Style and Motion through revealing puzzle questions so that interrogative sentences are used. The stages of the process include practices and reiterate. The expected goals in this stage are:

(1) conducting evidence to solve phenomena or experimental results; (2) comparing the "genuineness" of the problem with their initial conception; (3) developing and evaluating conceptions scientifically; and (4) building stronger conceptions using different discrepant events. In order to support this goal, it is necessary to design visual multimedia such as video phenomena, video animation, and equipment that supports and can explain the discrepant event phenomenon. Whereas in the third stage in the form of evaluation, it aims to map learning progression and conceptual change for preservice elementary school teachers' conceptions about Force and Motion. 


\section{Data Analysis}

The type of data is quantitative data obtained from the results of the pretest and posttest. The pretest and posttest data were analyzed to know increasing after using the STEM integrated handouts through 10 items. The amount of increase is calculated by the formula:

$$
N-\text { gain }=\frac{\text { posttest }- \text { pretest }}{\text { score } \text { max }- \text { pretest }} \times 100
$$

The results of the N-gain calculation are interpreted using classification (Table 1).

Table 1. N-gain Classification

\begin{tabular}{ll}
\hline $\mathbf{N}$-gain & Classification \\
\hline $\mathrm{N}$-gain $>0,7$ & High \\
\hline $0,3<\mathrm{N}$-gain $\leq 0,7$ & Medium \\
\hline $\mathrm{N}$-gain $\leq 0,3$ & Low \\
\hline
\end{tabular}

The results of $\mathrm{N}$-gain calculation of students creative thinking skills in experiment class and control class could be interpreted using classification (Table 2).

Table 2. Classification Score of Creative Thinking

\begin{tabular}{cc}
\hline Percentage (\%) & Classification \\
\hline $81-100$ & Very High \\
\hline $61-80$ & High \\
\hline $41-60$ & Medium \\
\hline $21-40$ & Low \\
\hline $0-20$ & Very Low
\end{tabular}

\section{RESULTS AND DISCUSSION}

\section{Students Creative Thinking Skills}

The effectiveness of STEM integrated handouts on students creative thinking skills have shown at Table 3.

Table 3. Average of N-gain Creative Thinking Skills

\begin{tabular}{llll}
\hline & Group & Average Score & Classification \\
\hline \multirow{2}{*}{ N-gain } & $\begin{array}{l}\text { Experiment } \\
\text { Class }\end{array}$ & 0.64 & Medium \\
\cline { 2 - 4 } & Control Class & 0.40 & Medium \\
\hline
\end{tabular}

Based on the data in Table 3, there are differences between $\mathrm{N}$-gain of experiment class and control class where the N-gain of experiment class using the STEM integrated handouts was greater than the N-gain of control class that use text book.

Table 4. Percentage of students Creative Thinking Skills

\begin{tabular}{lcc}
\hline \multicolumn{1}{c}{ Groups } & Percentage (\%) & Classification \\
\hline Experiment Class & 28.57 & High \\
\cline { 2 - 3 } & 71.43 & Medium \\
\hline Control Class & 5.71 & High \\
\cline { 2 - 3 } & 65.71 & Medium \\
\cline { 2 - 3 } & 28.57 & Low \\
\hline
\end{tabular}

Based on the data in Table 4, the students creative thinking skills of the experiment class was greater than the control class, because no students have the "low" category in the experiment class and no students have the "high" category in the control class. This shows that the use of STEM integrated handouts is more effective than using text book. 


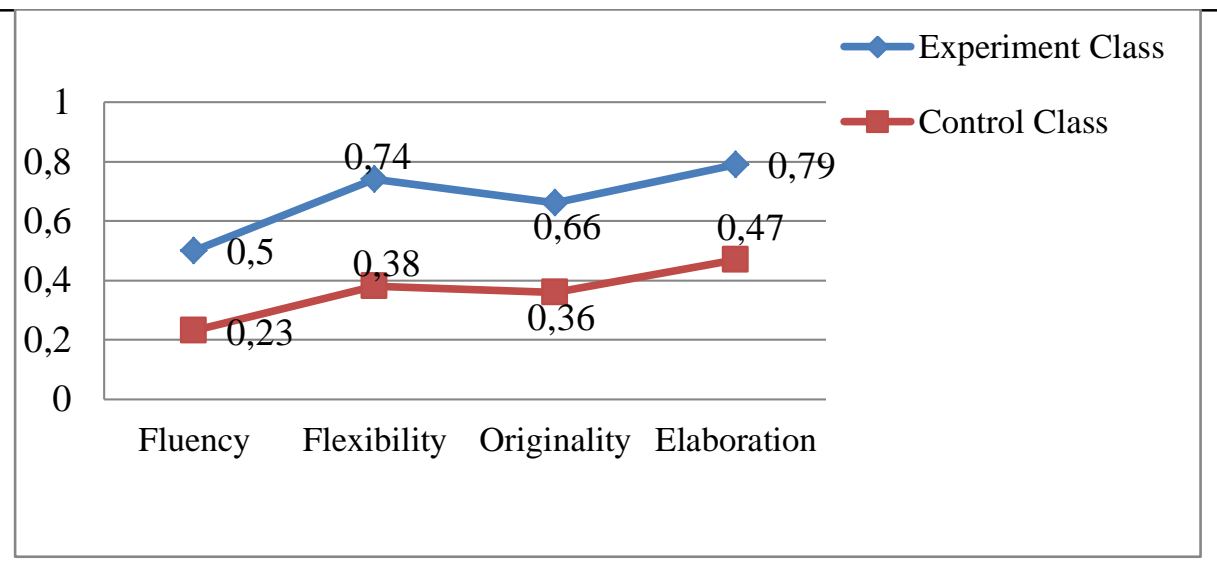

Figure 1. Increasing Creative Thinking Skills for Each Indicators

Based on the results of the tests conducted on each indicator of creative thinking, all indicators of creative thinking skills in the experiment class have increased after using the STEM integrated handouts in learning. Indicators of fluency and originality have "medium" category. Meanwhile, indicators of flexibility and thinking of elaboration have "high" category. In the control class, for fluency have "low" category. Meanwhile, indicators of flexibility, originality, and elaboration have "medium" category. Based on the results of $\mathrm{N}$-gain calculation, the achievement of indicators of creative thinking, it is known that the highest indicator of in the experiment class is elaboration. It can be concluded that the creative thinking skills for each indicators of experiment class increases after using the STEM integrated handouts.

The amount of N-gain in the experiment class (Table 3) was caused by handouts as an instructional materials for handouts which were used to supplement teaching materials that have deficiencies in achieving the objectives in the learning process that couldbe adjusted to the characteristics of students, types of subject matter, situations and could motivate and improve students learning in biology and it developed based on the conditions of students in accordance with the purpose of learning that apply the material in the learning process in daily life clearly [14]. This is supported by Rahmayani [15] which states that handouts are able to complement the weaknesses of textbooks in the learning process and more effective used in learning on biotechnology material.

Increasing creative thinking skills for each indicator (Figure 1) because the teacher guides students in explaining the activities of varying experiments and making project assignments by applying the STEM approach. At the first meeting the teacher provides guidance to students to follow the procedure of varying the variables contained in the handout, so that students are able to complete all activities in the handout. Learning activities that are integrated with STEM could be an alternative in improving all skills needed in the 21st century [16]. This is supported by the statement that STEM is a meta-discipline at the school where teachers of science, technology, engineering and mathematics teach education as a dynamic entity. STEM is an approach that explores learning between two or more STEM subject areas and / or between STEM and other school subjects, for example technology cannot be separated from social learning, arts and humanities [17]

Table 5. Students Responses

\begin{tabular}{ccc}
\hline Aspects & Presentase (\%) & Kriteria \\
\hline Attractiveness & 82 & Very Interesting \\
\hline Usefullness & 83 & Very Usefull \\
\hline Legibility & 80 & Very Legible \\
\hline
\end{tabular}

Based on the students responses (Table 5) almost all students are interested using STEM integrated handouts because students are trained to conduct experiment activities and observations by the groups. The benefits obtained are students understand steps in working on a project in the form of biotech products and more creative because it provides an opportunity to vary the tools and materials in making biotech products. It was caused the learning environment supports student activities to complete all activities in the handouts, so that to create a learning climate that supports students to solve problems, appropriate strategies are needed in order to develop students thinking skills [16]. 


\section{CONCLUSION}

Based on the results and discussions, it could be concluded that the handouts shows its role as an innovative teaching material in increasing students involvement to be active in the learning process. It has given the implication for the importance of creating variety of teaching materials for science learning which more meaningful and will provide provisions for the younger generation in facing the 21st century. STEM-integrated handouts could improve students' creative thinking skills in biotechnology materials and handouts was more effective in learning.

\section{ACKNOWLEDGMENTS}

The researcher presents the appreciation goes to both of my advisor Dr. Abdurrahman, M.Si., and Dr. Tri Jalmo, M.Si., for supervision, advice and guidance from very early stage of this research and helped me patiently finishing this research. I thank gratefully to all science teachers and students Nine Graders at SMPN 25 Bandar Lampung, Indonesia for allowing me to conduct the research there, and also my family of Master of Teacher Training and Science in Science Education in Lampung University who have been contribution and support during the study.

\section{REFERENCES}

[1] Dharma 2008 Kreativitas (Jakarta: Direktorat Jenderal Peningkatan Mutu Pendidik dan Tenaga Kependidikan Departemen Pendidikan Nasional)

[2] Richard F, Mellander C, and King K 2015 The Global Creativity Index 2015 Toronto

[3] Mufiannoor E 2016 Melatihkan Kemampuan Berpikir Kreatif Dan Pemahaman Konsep dengan Pembelajaran Berbasis Inkuiri Terbimbing Pada Materi Interaksi Makhluk Hidup Dengan Lingkungan J. Penelitian Pendidikan Sains 5(2) 934-

[4] Munandar U 2001 Mengembangkan Bakat dan Kreatifitas Anak Sekolah (Jakarta: PT Gramedia Widiasarana)

[5] Becker K and Park K 2011 Effects Of Integrative Approaches Among Science Technology Engineering And Mathematics (STEM) Subjects On Students Learning A Preliminary MetaAnalysis J. STEM Education Innovations and Research 22(5/6) 23

[6] Permanasari A 2016 STEM Education Inovasi dalam Pembelajaran Sains Seminar Nasional Pendidikan Sains (Surabaya: Universitas Sebelas Maret)

[7] Beers S 2011 21st Century Skills Preparing Students For Their Future. http://www.yinghuaacademy.org/wp-content/uploads/2014/10/21st_century_skills.pdf Access on February 42018

[8] Mayasari T, Kadarohman A, and Rusdiana D 2014 Pengaruh Pembelajaran Terintegrasi Science Technology Engineering And Mathematics (STEM) Pada Hasil Belajar Peserta Didik Studi Meta Analisis Prosiding Semnas Pensa VI 371-377

[9] Subramaniam MM, Ahn J, Fleischmann KR, and Druin A 2012 Reimagining The Role Of School Libraries In STEM Education Creating Hybrid Spaces For Exploration The Library Quarterly 82(2) 161-182

[10] Dewi HR 2017 Peningkatan Keterampilan Berfikir Kreatif Siswa Melalui Penerapan Inkuiri Terbimbing Berbasis STEM Seminar Nasional Pendidikan Fisika (Madiun: FKIP Universitas PGRI)

[11] Islam et al 2005 Students Perceptions of Technology-Based Lecture Handouts The Malaysian J. Of Medical Science 12(1) 26-8

[12] Fauzi M 2017 Pengembangan Bahan Ajar Berbentuk Handout Berbasis Sejarah Lokal dengan Materi Perjuangan Rakyat Banyumas Mempertahankan Kemerdekaan dalam Agresi Militer Belanda 1 Tahun 1947 Terhadap Minat Belajar Siswa Kelas XI SMA Negeri 4 Purwokerto, Indonesian J. of History Education (2) 37-43

[13] Hermawati M 2017 Pengembangan Handout Fisika Berbasis Experiental Learning untuk Meningkatkan Kemampuan Berpikir Kreatif Peserta Didik SMA (University Research Colloquium) 147-148

[14] Prastowo A 2013 Panduan Kreatif Membuat Bahan Ajar Inovatif Menciptakan Metode Pembelajaran Yang Menarik Dan Menyenangkan (Jakarta: DIVA Press) 
[15] Rahmayani F 2015 Pengembangan Handout Berbasis Kontekstual Pada Pelajaran Biologi Materi Bioteknologi Untuk Siswa Kelas XII SMK Negeri 02 Batu J. Pendidikan Biologi Indonesia 1(1) 47-59

[16] Abdurrahman dkk 2019 Designing an Inquiry-Based STEM Learning Strategy as a Powerful Alternative Solution to Enhance Students 21st Century Skills J. of Physics 1155 1-6

[17] Brown R, Brown J, Reardon K, and Merril C 2011 Understanding STEM: Current Perceptions Technology and Engineering Teacher 70(6) 5-9

\section{http://jurnalnasional.ump/index.php/dinamika}

